\title{
Secretion of Acid Sphingomyelinase is Affected by its Polymorphic Signal Peptide
}

\author{
Cosima Rhein ${ }^{\mathrm{a}}$ Martin Reichel ${ }^{\mathrm{a}}$ Christiane Mühle Andrea Rotter $^{\mathrm{a}}$ \\ Sibylle G. Schwab ${ }^{a, b}$ Johannes Kornhuber ${ }^{a}$ \\ ${ }^{a}$ Department of Psychiatry and Psychotherapy, University Hospital, Friedrich-Alexander-University \\ Erlangen-Nuremberg, Erlangen, Germany, ${ }^{b}$ Faculty of Science, Medicine and Health, University of \\ Wollongong, Wollongong, Australia
}

\section{Key Words}

Acid sphingomyelinase $\cdot$ Secreted and lysosomal form $•$ Signal peptide $\bullet$ Coding polymorphisms - TNF $\alpha$-induced secretion • Ceramide

\begin{abstract}
Background: Acid sphingomyelinase (ASM) catalyses the hydrolysis of sphingomyelin into ceramide, which acts as a lipid messenger that regulates important cellular functions. Deregulated ASM activity has been reported for different common diseases, but the mechanisms regulating ASM activity are still debated. ASM contains an exceptional signal peptide which is polymorphic due to a variable number of a hexanucleotide sequence that determines the length of the hydrophobic core. We investigated the impact of the signal peptide polymorphism on the regulation of ASM activity and secretion in vivo and in vitro. Methods and Results: Subjects homozygous for the rare 4-repeat allele displayed significantly lower secreted ASM activity than subjects homozygous for the common 6-repeat allele. In vitro, overexpression of ASM variants encoded by 2, 8 or 9 repeats resulted in a significantly lowered ASM secretion rate. Treatment of ASM-overexpressing cells with tumour necrosis factor $\alpha$ induced secretion of ASM, and the secretion rate was highest for the most common ASM variant encoding 6 repeats compared to other naturally occurring variants. Conclusion: We provide evidence that the polymorphic ASM signal peptide regulates ASM secretion. It might be an evolutionary mechanism to increase ASM secretion potential, whereas an increase in lysosomal ASM activity is limited due to deleterious cellular effects.
\end{abstract}

Copyright @ 2014 S. Karger AG, Basel

C. Rhein and M. Reichel contributed equally to this work.

Cosima Rhein, Ph.D.

Department of Psychiatry and Psychotherapy, University Hospital, Friedrich-AlexanderUniversity Erlangen-Nuremberg, Schwabachanlage 6, D-91054 Erlangen (Germany) Tel.+49-9131-85-44604, Fax +49-9131-85-36381, E-Mail Cosima.Rhein@uk-erlangen.de 


\section{Introduction}

Acid Sphingomyelinase (ASM, EC 3.1.4.12) generates ceramide by hydrolysing sphingomyelin, and it is therefore a key regulator of cellular sphingolipid metabolism [1]. The generation of ceramide is an important cellular reaction to stressful events $[2,3]$. Ceramide molecules aggregate spontaneously and fuse to large macrodomains [4-6]. These macrodomains play an important role in signal transduction processes and impact signal cascades [7, 8]. Ceramide and its metabolites act as lipid messengers. They promote a variety of cellular processes, ranging from apoptosis, senescence, differentiation, migration, angiogenesis, and autophagy to inflammation [9-11]. The balance between apoptosis and proliferation in the cell is maintained by the complex interplay between two bioactive sphingolipids. Increased ceramide levels promote apoptosis, whereas an increase in the phosphorylated metabolite of ceramide, sphingosine-1-phosphate, counteracts this effect by inducing proliferation [12]. This 'ceramide / sphingosine-1-phosphate rheostat' concept describes how the balance between cell death and cell growth is regulated $[12,13]$. Among the enzymes regulating the dynamic balance between the bioactive lipids, ASM holds a prominent position in that it generates the first bioactive molecule in this rheostat.

The sphingomyelin phosphodiesterase 1 (SMPD1) gene coding for ASM gives rise to two distinct enzymes. Upon processing a common precursor protein inside the Golgi, the secreted form (S-ASM) is finally released into the extracellular space, whereas the lysosomal form (L-ASM) is targeted to the endo-lysosomal compartment [14, 15]. As a result of the differential post-translational processing, L- and S-ASM are characterised by distinct biochemical properties. L-ASM encounters zinc during its processing steps inside the lysosome, whereas the activity of S-ASM requires additional zinc [16]. Both forms are glycosylated during Golgi trafficking, but only S-ASM is converted into a complex glycosylated protein $[17,18]$. Furthermore, both forms differ regarding their first amino acid at the N-terminus [16, 19-22].

Cytokines and other stimulating agents have differential effects on L- and S-ASM. In vivo, the induction of a systemic inflammation in mice by the application of lipopolysaccharide, tumour necrosis factor $\alpha$ (TNF $\alpha$ ), or interleukin (IL) $1 \beta$ is accompanied by increased S-ASM levels [23]. Data about the effects on L-ASM in this context has not been reported. The coregulation of S- and L-ASM activity was addressed in several cell culture systems. Romiti et al. [24] observed an increased S-ASM release from thrombin-stimulated platelets accompanied by decreased cellular L-ASM activity. Similarly, Jenkins et al. [15] observed increased S-ASM activity in MCF7 cells treated with phorbol myristate acetate accompanied by decreased L-ASM activity. The treatment with IL1 $\beta$ or TNF $\alpha$ in the same study resulted in increased S-ASM activity without affecting L-ASM activity [15]. Following treatment with IL1 $\beta$, interferon (IFN) $\beta$, or IFN $\gamma$, Marathe et al. [25] observed that S-ASM activity increased by 2 to 3.5-fold in human umbilical vein endothelial cells (HUVECs), and L-ASM activity decreased slightly. Thus, stimulation might selectively increase short-term S-ASM activity and secretion at the expense of L-ASM activity.

There is also emerging evidence that L- and S-ASM might differ in their contribution to specific pathologic states. Dramatically decreased L-ASM activity causes Niemann-Pick disease (NPD) types A and B, due to a variety of inherited missense mutations in the SMPD1 gene [26]. Low ceramide levels can be found in different types of cancer like colon cancer [27] and glioma [28]. Elevated L-ASM activity in human primary material has been described for Alzheimer's dementia [29], major depression [30], alcohol dependence [31] and infections [32]. Using murine models it was shown that L-ASM activity is increased in status epilepticus [33] and cystic fibrosis [34]. S-ASM activity is increased in patients suffering from alcohol dependence [35], Morbus Wilson [36], chronic heart failure [37], sepsis [38] and chronic hepatitis C [39]. S-ASM was also increased in murine models of arteriosclerosis [40], pulmonary edema [41] and emphysema [42].

Despite the huge number of clinically important missense mutations in the SMPD1 gene, only a few reports have addressed the prevalence of common variants of ASM and their 
possible contributions to human disease. In a re-sequencing analysis of the coding region of SMPD1 [43] we estimated that there are three common non-synonymous polymorphic sites with a frequency of $>5 \%$ in the German population. An additional single nucleotide polymorphism (SNP) encoding the variant p.A487V, which was originally assumed to be a clinically relevant missense mutation, occurred with a frequency of about $1 \%$ [43]. The only common non-synonymous SNP that affects the mature ASM enzyme is rs1050239 (c.1522G>A; p.G508R) with a minor allele frequency between $16 \%$ and $27 \%$ in different studies [44-46]. The polymorphism results in the amino acid substitution Gly>Arg at position 508 in the C-terminus of ASM and it is associated with altered cholesterol levels, familial history of coronary artery disease [44], self-reported allergy and decreased in vivo S-ASM activity [45]. The two other common polymorphisms, rs1050228 (c.107T>C; p.V36A) and a hexanucleotide repeat (c.108GCTGGC(3_8); p.37LA(3_8)) reside within the putative signal peptide of the ASM pro-form that is not part of the mature enzyme. The signal peptide was shown to be essential for the production of an intact enzymatically active mature ASM, and ASM constructs with $\mathrm{N}$-terminal truncations of the signal sequence lacked catalytic activity [17]. Wan and Schuchman [47] were the first to analyse the polymorphic hexanucleotide repeat encoding a variable number of Leu-Ala (LA) repeats. They identified five alleles with different repeat numbers, but the frequencies were similar for healthy individuals and patients with NPD types A and B. Recently, Dastani et al. [44] observed that the repeat number was associated with the prevalence of hypertension and plasma triglyceride levels in people with low high-density lipoprotein cholesterol.

In the present study, we combined clinical and biochemical analyses to investigate the hypothesis that the polymorphic site in the signal peptide of ASM can affect ASM activity. We found evidence from both approaches that predominantly S-ASM activity is regulated differentially by the polymorphic site. In vivo, S-ASM activity was decreased in subjects homozygous for 4 repeats compared to those with the most prevalent motif of 6 repeats. In vitro studies elucidated that extreme length of the signal peptide decreases the secretion of ASM without affecting cellular ASM activity. Interestingly, the signal peptide polymorphism affects the secretion of ASM induced by the inflammatory cytokine TNF $\alpha$. The secretion rate was significantly lower for the 4LA-repeat ASM variant compared to the ASM wild-type with 6LA-repeat. Thus, despite the signal peptide being cleaved very early in ASM maturation, it has significant influence on the post-cleavage functioning of ASM. The signal peptide might serve as an evolutionary evolved mechanism to boost ASM secretion potential, although the increase in L-ASM activity is limited due to deleterious cellular effects.

\section{Materials and Methods}

\section{Clinical study}

Study sample. ASM genotypes and ASM activity were initially analysed in 156 healthy individuals enrolled in the GENES study [45, 48-50]. Further data were obtained from the ASPECT control group ( $n=133$ ) [31]. All studies were carried out at the Department of Psychiatry and Psychotherapy at the University of Erlangen-Nuremberg. The study protocols were approved by the local Ethics Committee and conducted in accordance with the Declaration of Helsinki. Written informed consent was obtained from all participants.

Genotyping of ASM. Genomic DNA was isolated from whole blood using the Gentra Puregene Blood Kit (Qiagen, Hilden, Germany). The genotyping of rs1050239 was described previously [45]. The repeat number variation was determined by capillary electrophoresis of fluorescent-labelled PCR products on an ABI Prism 3100 Genetic Analyzer (Applied Biosystems, Carlsbad, CA). Previously described oligonucleotides [47] ASM_ repeat_fw (5'-GGACTCCTTTGGATGGGCCT-3') and ASM_repeat_rev*FAM (5'-CTTTGCAGATTGGGCAGG-3') were used with the following PCR conditions: $1.5 \mathrm{U}$ Tfi polymerase (Invitrogen, Darmstadt, Germany), 300 $\mu \mathrm{M}$ dNTPs, $1.5 \mathrm{mM} \mathrm{MgCl}_{2}, 240 \mathrm{nM}$ of each oligonucleotide, and $50 \mathrm{ng}$ of genomic DNA in a total volume of 15 $\mu \mathrm{l}$, which were incubated initially for $2 \mathrm{~min}$ at $94^{\circ} \mathrm{C}$, and subjected to $30 \mathrm{cycles}$ of $30 \mathrm{~s} \mathrm{at} 94^{\circ} \mathrm{C}, 1 \mathrm{~min}$ at $58^{\circ} \mathrm{C}$, and $1 \mathrm{~min}$ at $72^{\circ} \mathrm{C}$, and finished for $3 \mathrm{~min}$ at $72^{\circ} \mathrm{C}$ on a Labcycler (Sensoquest, Göttingen, Germany). SNP rs1050228 was determined by PCR and cycle sequencing using the primers 5'-AGGGCTGGCTAGGGTCCAG-3' 
and 5'-AGCCCCAGCACTCCTTTCG-3'. PCR was performed in a total volume of $30 \mu \mathrm{l}$ using 50 ng of genomic DNA, $3 \mathrm{U}$ Tfi polymerase, $6 \mu \mathrm{l}$ of $5 \times \mathrm{Tfi}$ PCR reaction buffer, $250 \mu \mathrm{M}$ dNTPs, $1.5 \mathrm{mM} \mathrm{MgCl}, 200 \mathrm{nM}$ of each oligonucleotide, and $5 \% \mathrm{v} / \mathrm{v}$ dimethyl sulfoxide (DMSO). The cycling conditions (35 cycles) were as described above. Sequencing was performed in a $10 \mu \mathrm{l}$ volume, using $1 \mu \mathrm{l}$ of PCR product, $0.5 \mu \mathrm{l}$ of BigDye Terminator v3.1 Cycle Sequencing Kit (Applied Biosystems), $2 \mu \mathrm{l} 5 \times$ BigDye Terminator sequencing buffer, $500 \mathrm{nM}$ oligonucleotide and 5\% v/v DMSO. The reaction was subjected to 25 cycles of $30 \mathrm{~s}$ at $94^{\circ} \mathrm{C}, 15 \mathrm{~s}$ at $58^{\circ} \mathrm{C}$, and $60 \mathrm{~s}$ at $72^{\circ} \mathrm{C}$, and analysed on an Applied Biosystems 3730 DNA Analyzer.

Determination of L- and S-ASM activity in blood samples. The determination of S- and L-ASM activity was conducted as described previously [45].

\section{Overexpression studies of ASM variants}

Construction of expression plasmids. Cloning of the ASM wild-type-FLAG-N2 construct [51] into the pmCherry-N1 expression vector (Clontech, Mountain View, CA, USA) was carried out using the In-Fusion Advantage PCR Cloning Kit according to the manufacturer's instructions (Clontech, Mountain View, CA, USA). The primers for this procedure were: 5'-TCAGATCTCGAGCTCAAGCTTGCCGCCATGCCCCGCTACGGAGC-3' (forward) and 5'-CTCACCATGGTGGCGACCGGTACGCAAAACAGTGGCCTTGG-3' (reverse). The cycle parameters were as follows: initial denaturation at $95^{\circ} \mathrm{C}$ for $2 \mathrm{~min}, 35$ cycles of $98^{\circ} \mathrm{C}$ for $20 \mathrm{sec}, 68^{\circ} \mathrm{C}$ for 15 $\mathrm{sec}$, and $68^{\circ} \mathrm{C}$ for $1 \mathrm{~min}$, and a final extension at $68^{\circ} \mathrm{C}$ for $5 \mathrm{~min}$. Constructs were sequenced completely to exclude any mutations.

The QuickChange XL Site-Directed Mutagenesis Kit (Stratagene, La Jolla, CA, USA) was used to mutate the ASM wild-type sequence by PCR. Mutagenesis was done according to the manufacturer's instructions starting from the ASM wild-type-cherry construct with 6 hexanucleotide repeats using the forward primer 5'-TGGTGCTGGCGCTGGCTCTGT-3' to obtain the ASM-cherry construct with 5 repeats. Successively, all further ASM-cherry variants containing different numbers of the repeat were derived. The cycle parameters were as follows: initial denaturation at $95^{\circ} \mathrm{C}$ for $1 \mathrm{~min}, 18 \mathrm{cycles}$ of $95^{\circ} \mathrm{C}$ for $50 \mathrm{sec}, 60^{\circ} \mathrm{C}$ for $50 \mathrm{sec}$, and $68^{\circ} \mathrm{C}$ for $6 \mathrm{~min}$, and a final extension at $68^{\circ} \mathrm{C}$ for $7 \mathrm{~min}$. Constructs were sequenced completely to exclude any spontaneous further mutations.

Cell Culture. H4 cells (Promochem, Wesel, Germany) were cultured in DMEM supplemented with 10\% (v/v) FCS and $4 \mathrm{mM} \mathrm{L-glutamine.} \mathrm{Cells} \mathrm{were} \mathrm{maintained} \mathrm{at} 37^{\circ} \mathrm{C}$ in a humidified atmosphere with $8.5 \% \mathrm{CO}_{2}$ as recommended by the supplier and monitored for potential mycoplasma infection using the MycoAlert Mycoplasma Detection Kit (Lonza, Cologne, Germany). All reagents used for cell culture were purchased from Biochrom (Berlin, Germany). For transfection purposes, cells were grown to $60 \%$ confluence in 6 -well plates with $2 \mathrm{ml}$ of culture medium. Transfections were performed by the calcium phosphate precipitation procedure. $7.5 \mu \mathrm{g}$ of plasmid DNA were mixed with $2 \mathrm{x} \mathrm{N,N-Bis(2-hydroxyethyl)-2-aminoethanesulfonic}$ acid (BES) buffer [50 mM BES, $280 \mathrm{mM} \mathrm{NaCl}, 1.5 \mathrm{mM} \mathrm{Na}_{2} \mathrm{HPO}_{4}$, pH 6.98; all chemicals were obtained from Sigma-Aldrich (Munich, Germany)]. This mixture also contained $10 \mu \mathrm{l}$ of $2.5 \mathrm{M}$ calcium chloride. This was then incubated for $20 \mathrm{~min}$ at room temperature, and added to cells. The culture medium was changed $17 \mathrm{~h}$ after transfection. The transfection efficiency was approximately $70-80 \%$, as determined by the number of GFP-positive cells after a parallel control transfection with the expression vector pmaxFP-green-C (Lonza, Cologne, Germany). Cells were serum-starved overnight and stimulated with TNF $\alpha$ ( $50 \mathrm{ng} / \mathrm{ml}$; Promokine, Heidelberg, Germany) for $24 \mathrm{~h}$. Transfected cells were lysed in RIPA buffer [50 mM Tris-HCl (pH 7.5), 150 $\mathrm{mM} \mathrm{NaCl}, 1 \% \mathrm{NP}-40,0.5 \%$ sodium deoxycholate, 0.1\% SDS (Sigma-Aldrich, Munich, Germany), into which were dissolved complete protease inhibitor tablets from Roche (Mannheim, Germany)]. Cell debris was removed by centrifugation at $1,000 \mathrm{~g}$ for $5 \mathrm{~min}$ at $4^{\circ} \mathrm{C}$. Conditioned medium was collected and centrifuged at $800 \mathrm{~g}$ for $5 \mathrm{~min}$ at $4^{\circ} \mathrm{C}$.

Acetone protein precipitation. To precipitate protein from the conditioned medium, the acetone protein precipitation method was applied. $1.5 \mathrm{ml}$ of acetone that was pre-cooled to $-20^{\circ} \mathrm{C}$ was added to $500 \mu \mathrm{l}$ of conditioned medium. Upon vortexing, an incubation step was performed for 120 minutes at $-20^{\circ} \mathrm{C}$. After centrifuging for 10 minutes at $13,000 \mathrm{~g}$, the supernatant was discarded, and the pellet was air-dried. For Western blotting, the pellet was dissolved in $50 \mu$ l of RIPA buffer.

Peptide-N-glycosidase F digestion (PNGase F). To remove N-linked glycosylation, PNGase F (SigmaAldrich, Munich, Germany) digestion was applied according to the manufacturer's instructions. $10 \mu \mathrm{l}$ of 250 mM phosphate buffer at $\mathrm{pH} 7.5$ along with $2.5 \mathrm{ml}$ of $2 \%$ SDS with $1 \mathrm{M} 2$-mercaptoethanol were added to 30 $\mu \mathrm{l}$ of RIPA buffered cell lysate. Upon heating at $100{ }^{\circ} \mathrm{C}$ for 5 minutes, the mixture was cooled down and 2.5 
$\mathrm{ml}$ of $10 \%(\mathrm{v} / \mathrm{v})$ Triton $\mathrm{X}-100$ was added. Incubation with PNGase F solution (0.01 U) was applied for 3 hours at $37^{\circ} \mathrm{C}$. The cleavage pattern was assessed by subsequent Western Blot analysis.

Western blot analysis. The protein concentration of the cell extracts was determined using the Coomassie (Bradford) Protein Assay Kit (Pierce, Rockford, USA). Western blot analysis was conducted as described previously $[43,51]$. The blots were incubated for $4 \mathrm{~h}$ at $4^{\circ} \mathrm{C}$ with the primary goat antiSMPD1 antibody (1:200; R\&D, Abingdon, UK) and then for $1 \mathrm{~h}$ with secondary rabbit anti-goat IgG antibody, coupled to horseradish peroxidase $(1: 10,000$; Dianova, Hamburg, Germany). All antibodies were diluted in 3\% milk powder solution (Roth, Karlsruhe, Germany) and $0.1 \%$ Tween 20 in PBS (SigmaAldrich, Munich, Germany). Detection was performed using the chemiluminescence (ECL select) Western blotting detection system (Amersham, Munich, Germany) and visualised on a high-sensitivity camera device (FluorSMax, Bio-Rad, Munich, Germany).

In vitro determination of $L$ - and S-ASM activity. Activity of overexpressed ASM was determined using the fluorescent substrate BODIPY-C12-sphingomyelin (Invitrogen, Darmstadt, Germany). For L-ASM, $2 \mu \mathrm{l}$ of the cell lysate supernatant (typically corresponding to $0.5-2 \mu$ g of protein) were added to 116 pmol of fluorescent substrate in sodium acetate buffer [ $200 \mathrm{mM}$ sodium acetate $\mathrm{pH} 5.0,500 \mathrm{mM} \mathrm{NaCl}$ and $0.2 \% \mathrm{NP}-$ $40]$ in a total volume of $100 \mu \mathrm{l}$. After incubation for 0.5 to $3 \mathrm{~h}$ at $37^{\circ} \mathrm{C}$, the fluorescent product ceramide and uncleaved substrate were extracted by the addition of $250 \mu \mathrm{l}$ chloroform/methanol $(2: 1, \mathrm{v} / \mathrm{v})$. Following vortexing and centrifugation, the lipid phase was concentrated in a SpeedVac vacuum concentrator and spotted on silica gel 60 plates (Macherey-Nagel, Düren, Germany). Ceramide and sphingomyelin were separated by thin layer chromatography using chloroform/methanol $(4: 1, \mathrm{v} / \mathrm{v})$ as a solvent and quantified on a Typhoon Trio scanner (GE Healthcare, $488 \mathrm{~nm}$ excitation and $520 \mathrm{~nm}$ emission wavelengths, $280 \mathrm{~V}, 100$ $\mu \mathrm{m}$ resolution) with QuantityOne software (Bio-Rad, Munich, Germany). S-ASM was measured by the same procedure with additional $500 \mu \mathrm{M} \mathrm{ZnCl}_{2}$ in the reaction buffer using a sample volume of $1.5 \mu \mathrm{l}$ serum-free medium and incubation times of 1-4 h. Measurements were performed at least in triplicates. The enzymatic activity of L-ASM was calculated as the rate of hydrolysis of sphingomyelin to ceramide per hour and per $\mu \mathrm{g}$ of protein $(\mathrm{pmol} / \mu \mathrm{g} / \mathrm{h})$. The enzymatic activity of S-ASM in the medium refers to the amount of protein of the respective cell lysate sample $(\mathrm{pmol} / \mu \mathrm{g} / \mathrm{h})$.

\section{Data analysis}

Deviation from Hardy-Weinberg equilibrium was assessed using chi-square test, and haplotypes were reconstructed from genotype data using the program PHASE v.2.1.1 [52]. Statistical analyses were performed with the software package IBM SPSS Statistics version 19. Variables were tested for normal distribution using the Kolmogorov-Smirnov test. The genetic effect on S- or L-ASM activity was calculated using ANOVA and Bonferroni post-hoc analysis. For cell culture experiments, statistical significance was calculated using t-test. A two-sided p-value $<0.05$ was considered to indicate statistical significance. All results are given as mean value \pm standard deviation (SD).

\section{Results}

Analysis of the three common coding polymorphisms in the SMPD1 gene

We identified three non-synonymous polymorphic sites with a frequency of $>5 \%$ (Fig. 1A, Table 1). One of the polymorphisms, the SNP rs1050239 (c.1522G $>$ A referenced to NM_000543.4; p.G508R referenced to NP_000534.3), is located in the C-terminus of ASM and associated with decreased S-ASM plasma abundance in vivo [45]. We therefore investigated 
whether the two other common polymorphisms affect ASM activity in vivo as well. Notably, rs1050239 is the only common variant that results in an amino acid substitution within the mature ASM enzyme. The two other sequence variants, SNP rs1050228 (c.107T>C; p.V36A) and the repeat number variation of a hexanucleotide sequence, lead to the modification of the signal peptide of the pro-pro-form of ASM

Table 2. Frequency of estimated SMPD1 haplotypes in the GENES study

\begin{tabular}{ccccc}
\hline c.107T $>$ C & c.108GCTGGC(3_8) & c.1522G $>$ A & n & $\%$ \\
\hline C & 6 & G & 151 & 48.4 \\
T & 5 & A & 71 & 22.8 \\
T & 5 & G & 58 & 18.6 \\
C & 4 & G & 17 & 5.4 \\
C & 8 & G & 7 & 2.2 \\
C & 6 & A & 3 & 1.0 \\
T & 6 & A & 2 & 0.6 \\
C & 4 & A & 2 & 0.6 \\
T & 4 & G & 1 & 0.3 \\
\hline
\end{tabular}
site was defined as the degenerated sequence $5^{\prime}$-CTGG(TC)(GT)-3' $[44,47]$. However, by considering the hexanucleotide motif as 5'-GCTGGC-3', the genomic situation is reflected more precisely (for instance, see the description of rs3838786 and rs71056748 in dbSNP), and it allows for the resolution of a compound polymorphic site into two independent variations that can be described systematically (Fig. 1C). In addition, their relevance can be addressed separately from each other.

We analysed the genetic configuration of SMPD1 in detail in the GENES collective of 156 healthy young individuals (Table 1). The polymorphic hexanucleotide sequence occurred in our sample with 4, 5, 6, and 8 repeats. Alleles displaying 6 repeats were found with the highest prevalence $(50.0 \%$; corresponding to the 7-repeat allele in earlier studies that used the degenerated hexanucleotide sequence for description). Alleles with 5 repeats occurred with $41.3 \%$ (termed the 6-repeat allele in earlier studies). Alleles with four and eight repeats occurred with a much lower frequency ( 6.4 and $2.2 \%$, respectively). These 4 alleles are combined into nine different genotypes (Fig. 1D). The majority of genotypes (86.5\%, $n=135)$ consisted of 5 and 6 repeats in homozygous or heterozygous configuration (5/5: 17.9\%; 5/6: $41.7 \%$; 6/6: 26.9\%). $9.6 \%$ of the genotypes $(n=15)$ were heterozygous combinations of one frequent allele (either 5 or 6 ) and one rare allele (either 4 or 8). Of the remaining genotypes, five subjects were homozygous for 4 repeats, and one carried the combination $4 / 8$. Thus, more than $50 \%$ of the subjects exhibited a heterozygous repeat configuration. Based on the genetic data for all three polymorphisms, nine haplotypes were reconstructed using the PHASE program [52]. The predominant haplotype consisted of the combination c.107C - 6 repeats - c.1522G (C-6-G), accounting for nearly $50 \%$ of the alleles (Table 2). Another $40 \%$ of alleles carried the haplotype T-5-A or T-5-G. Thus, the c.107T allele was found nearly exclusively in combination with 5 repeats and was associated with 4 or 6 repeats in only $2.3 \%$. Consequently, these haplotypes were termed the 'naturally predominant' ASM variants. As reported before by Dastani et al. [44], SNP c.1522A was preferentially present in combination with 5 hexanucleotide repeats. Thus, the genotypic distribution in our sample was similar to that described before.

The signal peptide polymorphism impacts S-ASM activity in healthy volunteers

Next, we calculated the effect of all three polymorphisms on the ASM activity in blood plasma (S-ASM) and in lysates of peripheral blood mononuclear cells (PBMC) (L-ASM) in 156 healthy subjects of the GENES study by one-way ANOVA. Because of the strong effect of rs1050239 [45] and its association with the other two polymorphisms, we observed a significant association with S-ASM activity for all three polymorphisms when tested individually (all $\mathrm{p}<0.001$ ). However, the influence of the c.107T $>\mathrm{C}$ polymorphism was lost when all three polymorphisms were taken into account simultaneously. None of the polymorphisms were associated with L-ASM activity (data not shown). For a clearer analysis, we selected subjects with homozygous repeat configurations $(4 / 4, n=5 ; 5 / 5, n=28$; $6 / 6, n=42$ ). This analysis confirmed the significant association of S-ASM activity with the number of hexanucleotide repeat $\left(\mathrm{F}=13.9, \mathrm{df}=2, \mathrm{p}=7.8 \times 10^{-6}\right.$; Fig. $\left.2 \mathrm{~A}\right)$. Bonferroni post-hoc analysis revealed statistically significant differences between subjects with 4 and 6 repeats 
Fig. 1. Common coding polymorphisms in the SMPD1 gene. A. Schematic representation of common polymorphic sites within the ASM protein. The sequence variant p.G508R (rs1050239; c.1522G>A) is located in the C-terminus of the mature enzyme, while p.V36A (rs1050228; c. $107 \mathrm{~T}>\mathrm{C}$ ) and the repeat number variation p.37LA(3_8) reside within a predicted transmembrane region of the putative signal peptide. The putative signal peptide (aa $1-48$ ) is indicated by a dark grey filling. B. The predicted transmembrane domain of the ASM signal peptide. The length of the repeat variation p.37LA(3_8) determines the hydrophobic core of the predicted transmembrane helix. The amino acid H62 is the putative signal peptide cleavage site. C. Resolution of the compound polymorphic site in the ASM signal peptide into two distinct polymorphisms. The single nucleotide polymorphism c.107T $>C$ is followed by a variable repeat number of the hexanucleotide motif

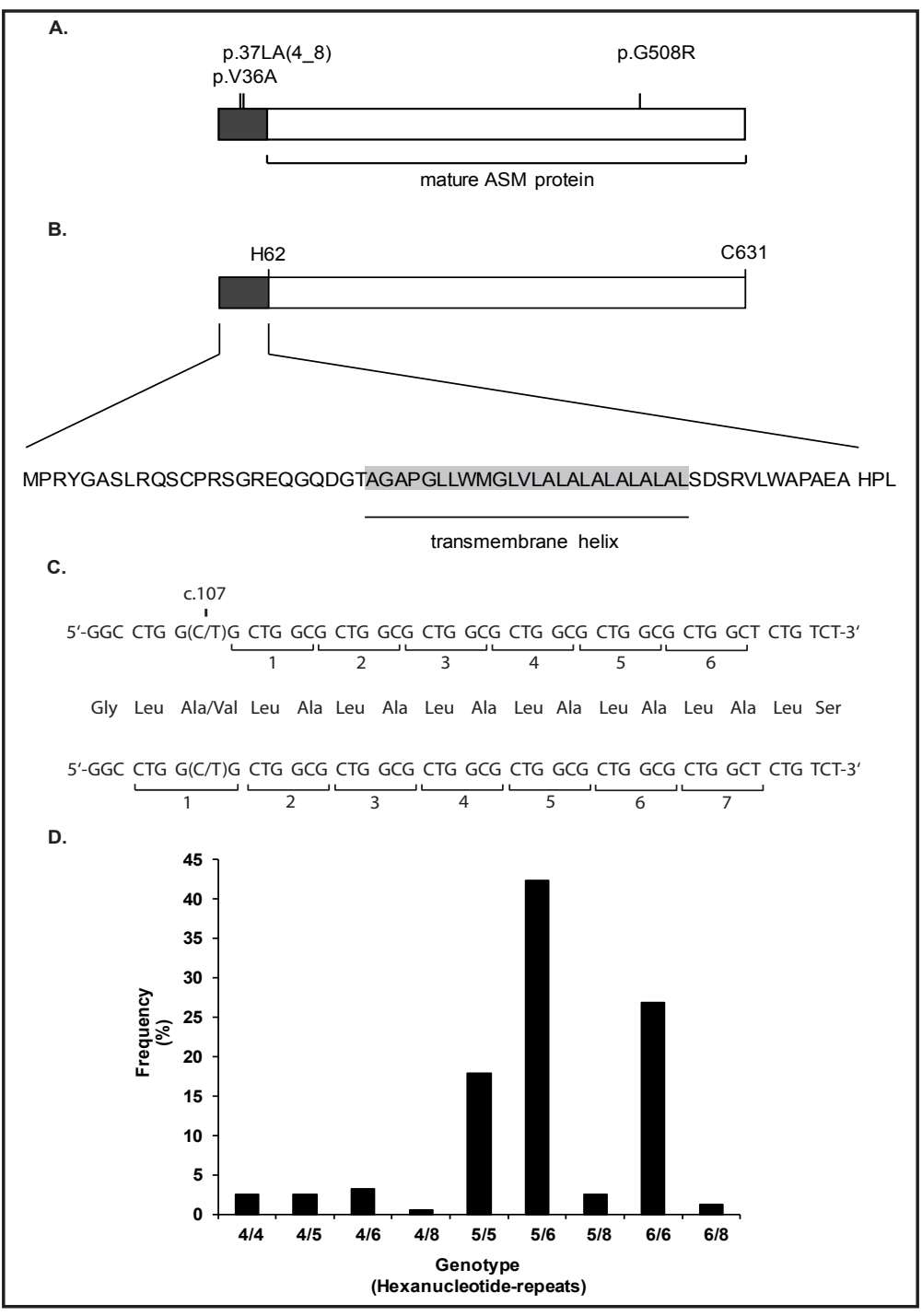
5'-GCTGGC-3' (upper lane). The number of repeats translates into the respective number of Leu-Ala dipeptides which comprise the core of a putative transmembrane domain. The SNP c.107T $>$ C determines whether the hypophobic core is extended at the N-terminal end by another Leu-Ala instead of a Leu-Val dipeptide. At the C-terminal site the hydrophobic core is terminated by a non-polymorphic Leu-Ser dipeptide (middle lane). Using the degenerated sequence 5'-CTGG(TC)(GT)-3' for the description of the genomic situation obscures the compound nature of the polymorphic site (lower lane). The nucleotide sequence of the reference NM_000543.4 (Pos. 100-150) and the amino acid sequence of the reference NP_000534.3 (Pos. 34-50) are given. D. Genotype prevalence. The genotype frequencies of the repeat motif varied highly in our study sample $(n=156)$. The combinations of $5 / 6(42 \%), 6 / 6(27 \%)$, and $5 / 5(18 \%)$ repeats are the genotypes with the highest prevalence.

$(\mathrm{p}=0.013)$ and between those with 5 and 6 repeats $\left(\mathrm{p}=1.7 \times 10^{-5}\right)$. The results revealed that S-ASM activity associated with the $6 / 6$ genotype was increased by $52 \%$ in comparison to the $5 / 5$ genotype and by $66 \%$ compared to the $4 / 4$ genotype. Importantly, 4 and 6 repeats were both preferentially found in the haplotype with c.107C and c.1522G, making it reasonable to speculate that the difference in S-ASM activity results indeed from the different length of the signal peptide. In order to confirm this hypothesis statistically with a greater number of samples, we combined data from two different studies (GENES and ASPECT, see 
Fig. 2. The signal peptide polymorphism impacts SASM activity in healthy volunteers. A. The 4-repeat genotype is associated with lower S-ASM activity. One-way ANOVA revealed statistically significant differences in S-ASM activity between healthy volunteers homozygous for $4(n=5), 5(n=28)$, and 6 $(n=42)$ repeats $\left(F=13.9, d f=2, p=7.8 \times 10^{-6}\right)$. Bonferroni post-hoc analysis revealed significant differences between 4 and $6(p=0.013)$ and 5 and 6 $\left(p=1.7 \times 10^{-5}\right)$ repeats. The boxplots show the median with the $25 / 75$ percentiles. B. Graphical representation of the independent effects of the repeat length and c.1522G $>$ A on S-ASM activity. Genetic data and z-transformed values for S-ASM activity from different studies (GENES and ASPECT, $n=289$ ) were combined. ANOVA confirmed that the hexanucleotide repeat had a significant effect on S-ASM activity independent from the influence of rs1050239 / c.1522G>A. Numbers of homozygous samples in this analysis: $4, n=6 ; 5, n=42 ; 6, n=74$. Data for S-ASM activity represent $\mathrm{z}$-transformed values; error bars denote SD.

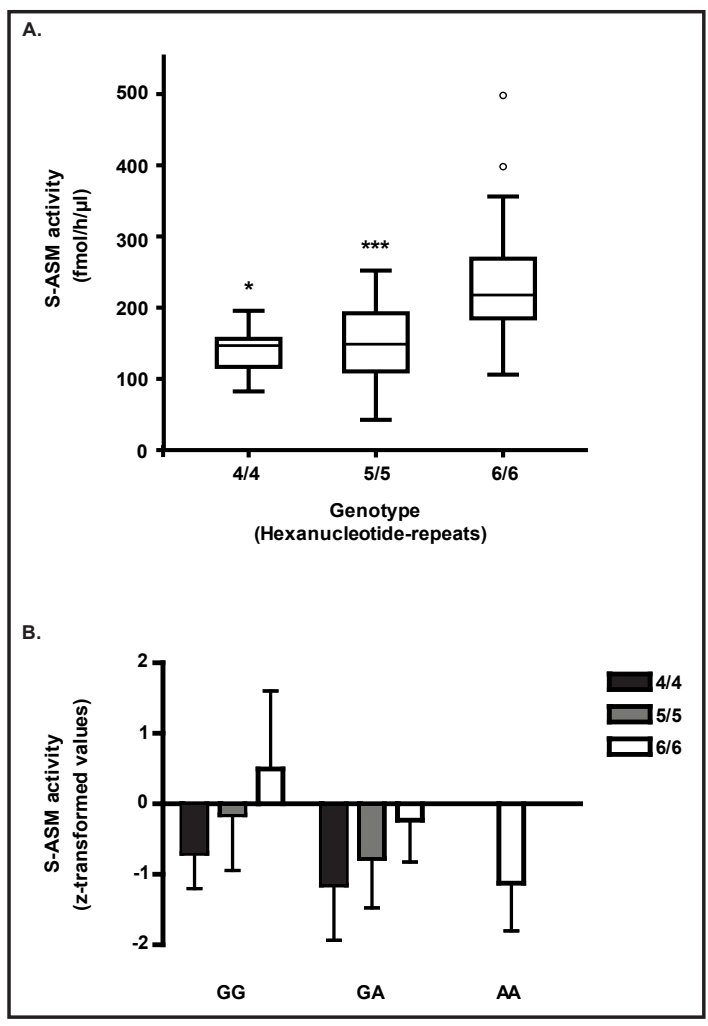

material and methods) and performed three-way ANOVA considering the effect of all three polymorphisms in a single analysis. This analysis confirmed that the hexanucleotide repeat, but not c.107T $>C$, had a significant effect on S-ASM activity independent from the influence of rs1050239 / c.1522G $>A$ (hexanucleotide repeat: $F=14.8, d f=3, p=4.01 \times 10^{-4}$; rs1050228: $\left.\mathrm{F}=0.430, \mathrm{df}=2, \mathrm{p}=0.651 ; \mathrm{rs} 1050239: \mathrm{F}=15.1, \mathrm{df}=2, \mathrm{p}=9.23 \times 10^{-5}\right)$. A graphical representation of the independent repeat motif effect is given in Fig. 2B.

The signal peptide polymorphism impacts S-ASM but not L-ASM activity in vitro

To further investigate the significance of the effect of the polymorphic hexanucleotide repeat for ASM biology, we performed in vitro studies using a cultured cell line. Plasmids coding for ASM variants with 1 to 9LA repeats combined with the LV dipeptide (p.V36) in the signal peptide and glycine (p.G508) at position 508 in the C-terminus of ASM were generated by site-directed mutagenesis and transiently overexpressed in $\mathrm{H} 4$ cells. The conditioned medium was collected and analysed for enzymatic activity of S-ASM. Overexpression of the ASM variant containing 6LA repeats, which is defined as the ASM wild-type (GenBank Accession Number NM_000543.4), significantly increased ASM activity levels by 120 -fold compared to endogenous levels with a control plasmid. Similar results were obtained for ASM variants with $3,4,5$, or $7 \mathrm{LA}$ repeats. In contrast, ASM variants containing the extreme motifs of $1,2,8$, or 9LA repeats resulted in significantly lower levels of S-ASM activity compared to the ASM wild-type with 6LA-repeat (Fig. 3A).

To determine ASM protein expression levels, total proteins were precipitated from conditioned medium and subjected to Western blot analyses. Analogous to S-ASM activities, the expression of the protein corresponding to the size of the active ASM isoform was very strong upon overexpression of ASM variants with 3, 4, 5, 6, and 7LA repeats, but hardly detectable for ASM variants with the extreme motifs of 1, 2, 8, or 9LA repeats (Fig. 3B).

The overexpression of ASM wild-type with 6LA-repeat in H4 cells significantly increased the L-ASM activity in cell lysates by about 9-fold compared to endogenous levels. Except for the ASM variant with the 1LA-motif, no significant differences in ASM activity were found 
Fig. 3. The signal peptide impacts secretion of ASM. A. S-ASM activity. Overexpression of the ASM wildtype with 6LA-repeat significantly increased S-ASM activity levels compared to control conditions. Similar results were obtained for ASM variants with $3,4,5$ or $7 \mathrm{LA}$ repeats. In contrast, ASM variants containing 1 , 2, 8 or 9LA repeats exerted significantly lower levels of S-ASM activity. $\mathrm{H} 4$ cells were transfected with $7.5 \mu \mathrm{g}$ of the respective ASM-cherry construct. Upon overnight serumstarvation, conditioned medium was analysed for S-ASM activity using the enzyme activity assay. The cloning vector served as a negative control. The displayed data represent mean values of triplicates, and error bars denote SD. Results were replicated three times. Statistical significance was calculated with respect to the reference variant ASM wild-type (6LA) using t-test $\left({ }^{*} \mathrm{p}<0.05,{ }^{* *} \mathrm{p}<0.01,{ }^{* * *} \mathrm{p}<0.001\right)$. B. Western blot analysis of conditioned medium. Overexpression of the ASM wild-type increased the expression levels of active ASM ( $85 \mathrm{kDa}$ ) in conditioned medium compared to control conditions. Similar results were obtained for ASM variants with 3, 4, 5 or 7LA repeats. In contrast, the active $85 \mathrm{kDa}$ form was hardly detecta-

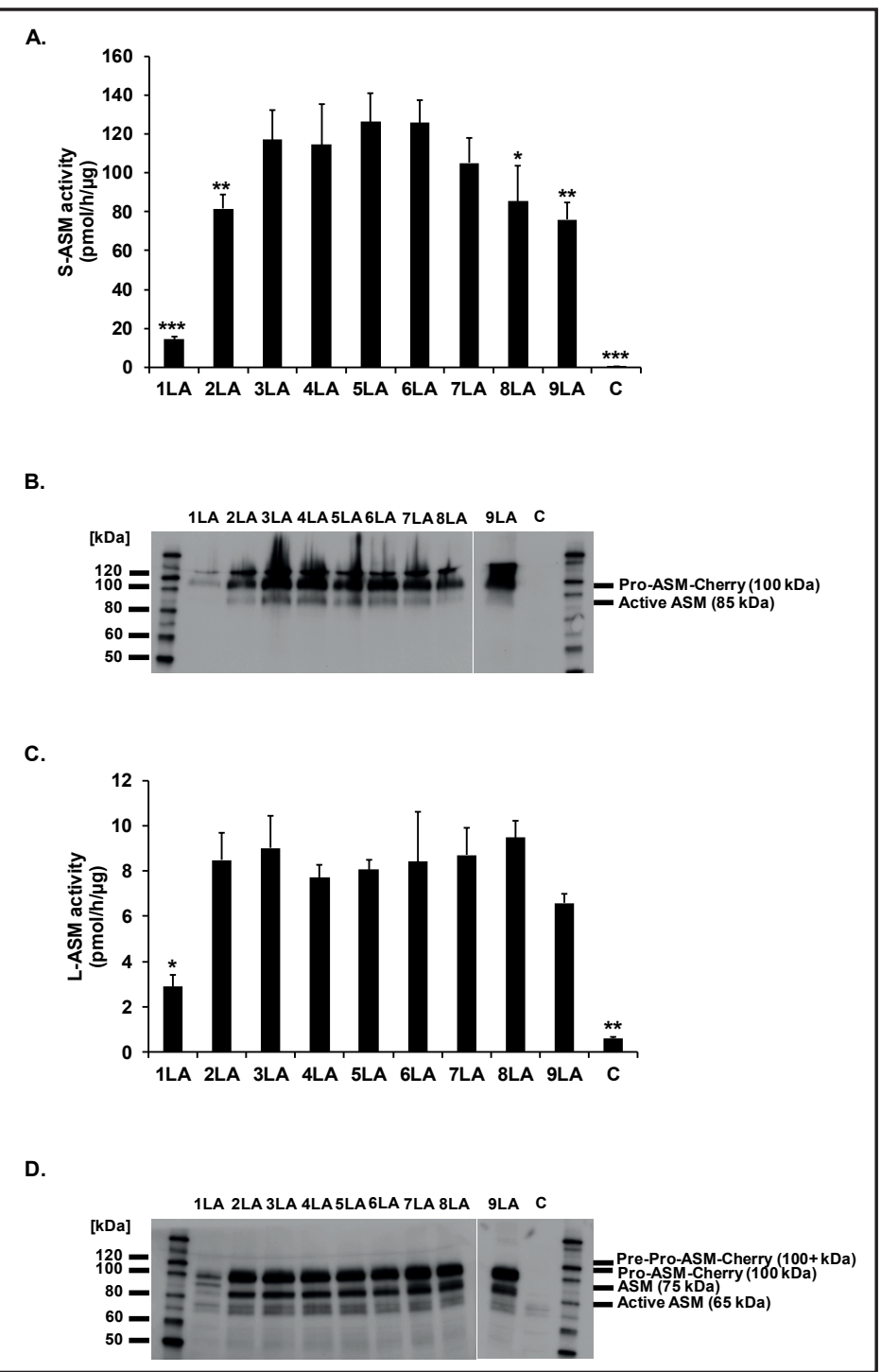
ble for ASM variants with the extreme motifs of 1, 2, 8 or 9LA repeats. Protein was precipitated from conditioned medium and analysed by Western blotting. ASM-cherry variants were detected using an anti-ASM antibody. The cloning vector served as a negative control. C. L-ASM activity. Overexpression of ASM wild-type (6LA) in H4 cells significantly increased the L-ASM activity in the cell lysates compared to control. Except for the ASM variant with the 1LA-motif, no significant difference in ASM activity was found for the other ASM variants. Cell lysates were analysed for L-ASM activity using the enzyme activity assay. Otherwise, methods and statistics were applied as described in 3A. D. Western blot analysis of cell lysates. Western blot analyses showed that cherry-tagged ASM variants were translated into proteins of the predicted sizes. With the exception of the ASM variant with the 1LA-motif, all other variants were expressed to a similar extent as ASM wild-type (6LA). Cell lysates were subjected to Western blotting. ASM-cherry variants were detected using an anti-ASM antibody. The cloning vector served as a negative control.

between the ASM variants (Fig. 3C). Western blot analyses showed that the variant ASMcherry constructs were translated into proteins of the predicted sizes. Using the antibody against ASM allows for the detection of an ASM-cherry pre-pro-form (ASM including the varying signal peptide $(75 \mathrm{kDa})$ and the cherry-tag $(30 \mathrm{kDa})$ adding up to a total of approximately $100 \mathrm{kDa}$ ), an ASM-cherry pro-form (ASM including cherry-tag but cleaved signal peptide), a C-terminally processed ASM form (ASM without cherry-tag; $75 \mathrm{kDa}$ ), and 


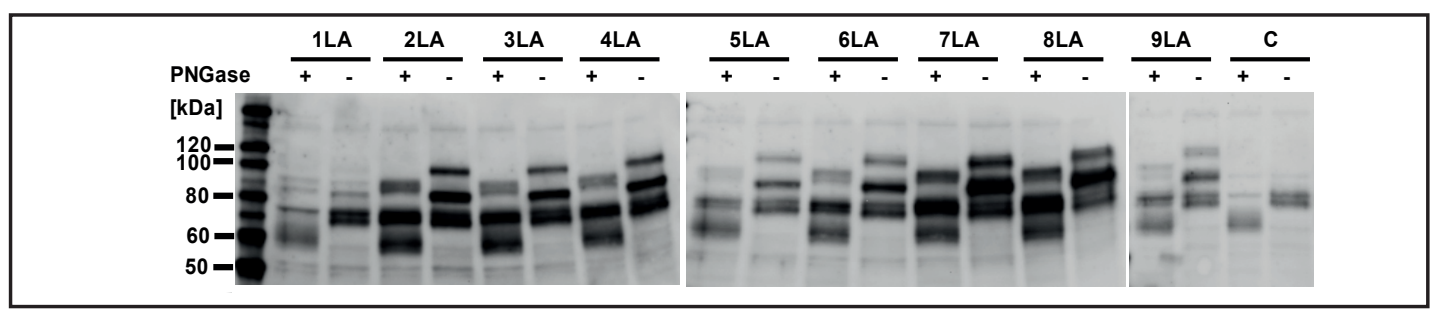

Fig. 4. The 1LA-motif is not sufficient to translocate ASM into the endoplasmic reticulum. Upon PNGase F digestion, all detected ASM bands (see Fig. 3D) were shifted to protein sizes minus $10 \mathrm{kDa}$ with the exception of the 1LA variant, for which no shift was detected. H4 cells were transfected with indicated variants, digested with 0.01U PNGase F for 22 h ("+"), and compared to control conditions ("-") by Western blotting using an anti-ASM antibody. The cloning vector served as a negative control.

the active ASM form (proteolytically cleaved ASM; $65 \mathrm{kDa}$ ). With the exception of the ASM variant with the 1LA-motif, all other variants were expressed to an extent similar to that of the ASM wild-type with 6LA-repeat (Fig. 3D).

The 1LA-motif does not serve as a functional signal peptide

To analyse whether the 1LA-motif serves as a functional signal peptide and is able to target the protein into the endoplasmic reticulum (ER), the glycosidase-sensitivity of the ASM signal peptide variants was investigated. Since N-glycosylation takes place selectively inside the ER lumen, this analysis indicates if a protein translocates into the ER [53]. Upon overexpression, cleared lysates were subjected to peptide-N-glycosidase F (PNGase F) digestion and subsequent Western blot analysis. PNGase F digestion leads to deglycosylation by releasing asparagine-linked (N-linked) oligosaccharides from glycoproteins, which results in a decrease of the protein mass of $10 \mathrm{kDa}$. Without PNGase F digestion, the ASM wild-type expression pattern was identical to those in the Western blot analysis in Fig. 3D. Upon PNGase F treatment, ASM protein bands were detected that were reduced to $90+, 90$, 65 and $55 \mathrm{kDa}$. The detection of glycosylated protein forms indicates the translocation of ASM wild-type into the ER. Compared to ASM wild-type, PNGase F treatment of ASM variants with LA-repeat $>1$ resulted in the same immunoreactive pattern. In contrast, the digestion of the 1LA ASM variant with PNGase F did not show protein bands that represent a glycosylated protein (Fig. 4). Thus, the 1LA-motif is not sufficient to serve as a signal peptide. The minimal requirement for a signal peptide seems to start from a 2LA-repeat motif.

\section{TNF $\alpha$-induced secretion of ASM is influenced by its signal peptide}

Due to the impact of the ASM signal peptide on secretion, we investigated the ASM secretion process more closely. ASM secretion is promoted by inflammatory cytokines, as shown in in vitro and in vivo models $[15,23,25]$. To investigate the impact of the ASM signal peptide polymorphism on TNF $\alpha$-induced secretion, $\mathrm{H} 4$ cells were transiently transfected with the naturally predominant ASM variants. Following stimulation of ASM-transfected cells with TNF $\alpha$ for $24 \mathrm{~h}$, S-ASM activity increased and L-ASM activity decreased for all tested ASM variants (Fig. 5A). However, transfection of the ASM wild-type with 6LA-repeat resulted in a stronger TNF $\alpha$-induced increase in S-ASM activity and a weaker decrease in L-ASM activity compared to the other natural variants. Regarding the ratio of S-ASM to L-ASM activity, the ASM wild-type with 6LA-repeat reached higher levels upon stimulation compared to the natural ASM variants with 4LA and 5LA repeats. The increase in the ratio of the S- to L-ASM activity of the 4LA-variant was significantly lower than for the ASM wildtype with 6LA-repeat upon stimulation with TNFa $(\mathrm{p}=0.047)$, whereas the 5LA-variant reached intermediate levels (Fig. 5B). Thus, although the signal peptide is cleaved early in ASM maturation, the length of its hydrophobic core has significant impact on the secretion of ASM upon stimulation with TNF $\alpha$. 
Fig. 5. TNF $\alpha$-induced secretion is influenced by the ASM signal peptide. A. Influence of TNF $\alpha$ on S- and L-ASM activities. Upon stimulation with TNF $\alpha$, S-ASM activity levels increased significantly for all natural ASM variants, while L-ASM activity levels decreased significantly only for the 4LA and 5LA-variant compared to respective control conditions. $\mathrm{H} 4$ cells were transfected with $7.5 \mu \mathrm{g}$ of the respective ASM-cherry construct. Upon overnight serum-starvation, cells were stimulated with TNF $\alpha(50 \mathrm{ng} / \mathrm{ml})$ for $24 \mathrm{~h}$. Cell lysates were analysed for L-ASM activity, and conditioned medium was analysed for S-ASM activity using the enzyme activity assay. The displayed data represent mean values of triplicates, and error bars denote SD. Results were replicated three times. Statistical significance was calculated with regard to the respective control condition using t-test $\left({ }^{*} \mathrm{p}<0.05\right)$. B. Ratio between S- and L-ASM activity. Upon stimulation with $\mathrm{TNF} \alpha$, the increase in the $\mathrm{S}$ to L-ASM activity ratio of the 4LA-variant was significantly lower than for the ASM wild-type (6LA). The ratio of S- and L-ASM activity is indicated as the percentage of the respective control condition. The displayed data represent mean values of $n=4$ independent experiments measured in triplicates, and error bars denote SD. Statistical significance was calculated with regard to the ASM wild-type (6LA) using t-test $\left({ }^{*} \mathrm{p}<0.05\right)$.

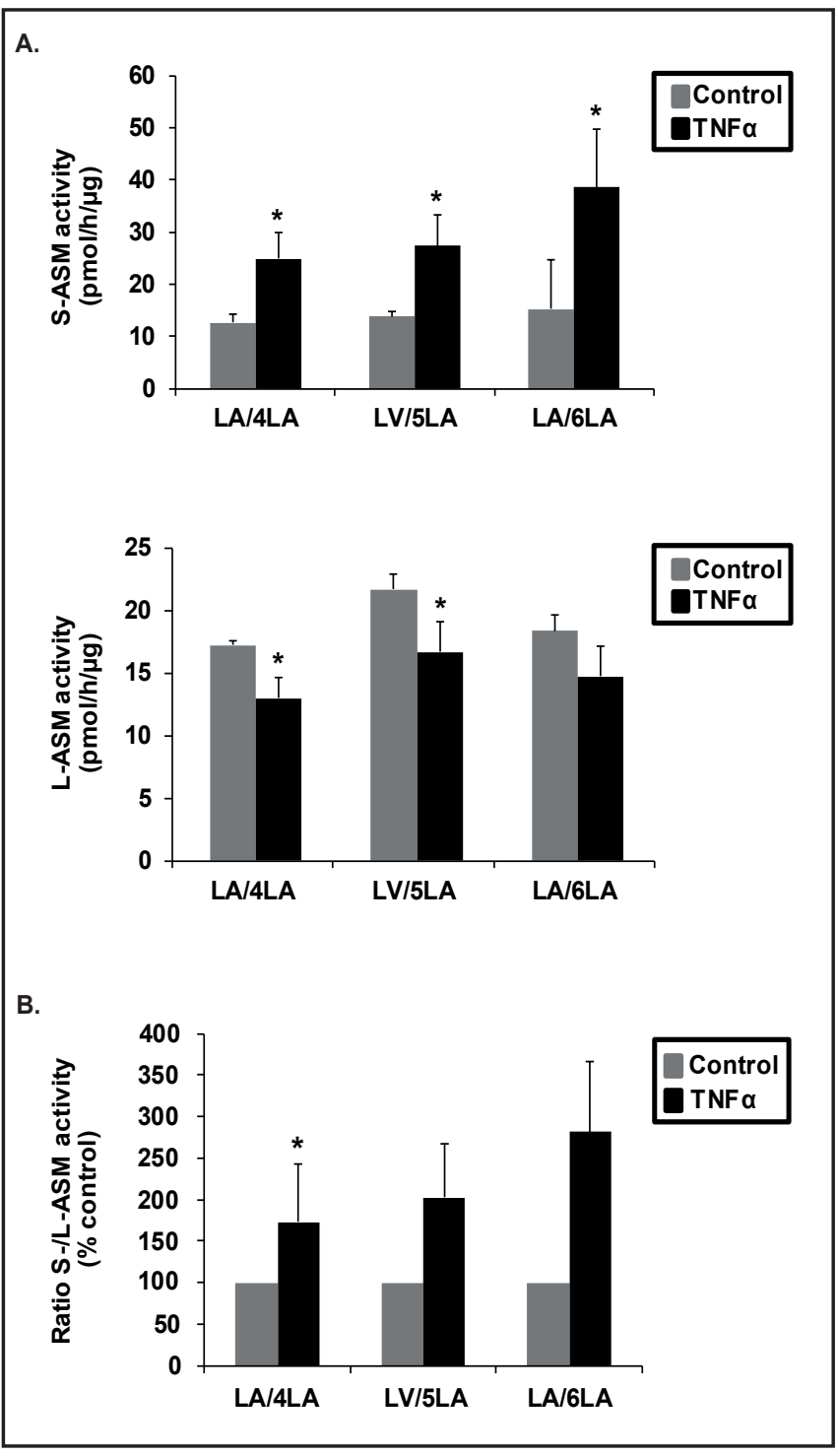

\section{Discussion}

In this study, we combined clinical and biochemical approaches to elucidate how genetic polymorphisms located within the signal peptide of ASM might influence the regulatory function regarding expression of the protein. The signal peptide of ASM is remarkable in several respects. Firstly, usual signal peptides consist of fewer than 25 amino acids (aa) with a short positively charged N-terminal region (called n-region), a 7- to 15-residue-long central hydrophobic core (h-region), and a polar C-terminal region (c-region) which defines the cleavage site [54]. In contrast, the signal peptide of ASM consists of $>48$ aa comprising an extended n-region ( $\geq 26$ aa), a predicted transmembrane domain (TMD) acting as an h-region (18 to 22 aa, depending on the prediction method used), and an ill-defined c-region which allows variable post-cleavage $\mathrm{N}$-terminal starting points of the maturated enzyme $[16,19$, $22]$. Thus, the signal peptide of ASM resembles more of an N-terminal anchor segment (type II signal anchor) $[55,56]$ that potentially encodes additional functions beyond the simple import to the endoplasmic reticulum such as specification of the targeting pathway, the efficiency of translocation, the timing of cleavage or post-cleavage functions [57]. Secondly, the hydrophobic core of the predicted TMD is variable in length due to a genetically stable 
polymorphic repeat number variation of a hexanucleotide motif encoding the dipeptide LeuAla. Interestingly, the length of a TMD has a strong impact on the localization of the respective protein $[58,59]$. Thus, the unusual structure of the ASM signal peptide might constitute a regulatory mechanism that controls the localization and thus the secretion of the enzyme. A similar effect on secretion exerted by a polymorphic signal peptide was described for apolipoprotein B (ApoB). Interestingly, ApoB displays a signal peptide polymorphism similar to that of the ASM, since it also comprises a Leu-Ala motif with an additional insertion (LeuLeu) or deletion (Leu-Ala-Leu) [60] that influences protein secretion rates [61]. In clinical studies, it has also been shown to influence the serum triglyceride levels [62], cholesterol and LDL-levels [63], cholesterol transport [64], and the onset of atherosclerosis and ischaemic heart disease $[65,66]$. Thirdly, while the presence of a variable region does not necessarily prove a functional relevance, the non-random distribution of repeat numbers in the ASM gene implies that the repertoire of existing alleles has been shaped by selection [67]. We therefore hypothesized that the polymorphic signal peptide might affect ASM biology.

Importantly, there is also genetic evidence pointing to a functional role of the ASM signal peptide. In a study of 118 subjects of French-Canadian descent, Dastani et al. [44] analysed the association of common ASM polymorphisms with severely reduced plasma high-density lipoprotein (HDL) cholesterol levels. Although the authors' original hypothesis of an association with low HDL-cholesterol levels could not be confirmed, they observed significant differences between affected subjects with $5 / 5,5 / 6$, and $6 / 6$ configurations for hypertension and triglyceride levels. Since Dastani et al. compared only the three most common genotypes (which comprised nearly $90 \%$ of cases, similar to our study), this leaves the possibility that subjects who carry at least one of the rarer alleles and comprise $<10 \%$ of the normal population are affected even more strongly.

Considering the great genotypic diversity among carriers of rare alleles and the strong linkage disequilibrium with other functional polymorphisms such a hypothesis would be hard to prove. In our clinical study, we investigated genetic data from 156 volunteers of the GENES study along with their data on S-ASM activity determined from plasma. In a previous study, we found that S-ASM activity is a more sensitive marker for a genetic influence compared to L-ASM activity [45], probably because of the higher turn-over rate of L-ASM [15]. Indeed, we showed that S-ASM activity, but not L-ASM activity, was associated with the number of the hexanucleotide motifs in the signal peptide. In order to reduce the genetic diversity of the sample and to designate the specificity of the effect for the polymorphic signal peptide, we selected subjects with a homozygous repeat configuration and conducted multi-way ANOVA. As a result, we found that 4 repeats were associated with a statistically significant lower S-ASM activity compared to 6 repeats. Five repeats were associated with intermediate S-ASM levels, but this comparison was confounded by the preferential combination of 5 hexanucleotide repeats with the minor allele of rs1050239 (c.1522A). Interestingly, as revealed by two-way ANOVA, only the haplotype consisting of 6 repeats together with the major allele of rs1050239 (which comprises nearly 50\% of the predominant haplotype) gave rise to above-average S-ASM activity, while all other genetic combinations resulted in below-average S-ASM activity (see Fig. 2B).

Our in vitro data using cloned ASM cDNA encoding different numbers of the hexanucleotide repeat confirmed the importance of this motif for proper ASM processing. We defined the minimal requirement for the translocation of the nascent ASM peptide with two hexanucleotide repeats. Transfection of a cloned variant encoding only one repeat only slightly increased L- and S-ASM activity. A detailed analysis revealed that this variant is not glycosylated, indicating that it was not properly imported into the endoplasmic reticulum. In contrast, cDNA variants encoding between 2 and 9 repeats resulted in L-ASM activity increased by nine-fold compared to controls. However, L-ASM activity associated with varying repeat lengths was not different, which is in agreement with our observation in the clinical sample that common variants do not affect L-ASM activity. Interestingly, S-ASM activity showed different effects compared to L-ASM activity in our assay. While the transfection 
of the most common variants increased S-ASM activity by 120 -fold compared to controls, transfection of variants with extremely low or high repeat numbers increased S-ASM to a significantly lower extent. Further analyses revealed that the proteolytic maturation of ASM was hampered in these variants.

Thus, our analyses revealed that the polymorphic ASM signal peptide affects L-and S-ASM differentially. Therefore, we questioned whether the polymorphic signal peptide would also affect ASM activity differentially under stimulating conditions. Our cell culture data showed a significant increase in S-ASM activity accompanied by a decrease in L-ASM activity upon stimulation with TNF $\alpha$. The observation of a significant increase of S-ASM activity at the expense of decreased L-ASM activity is in line with other studies which addressed the coregulation of L- and S- ASM in response to stimulating agents [15, 24, 25]. However, we could additionally show that the ASM signal peptide polymorphism influences the balance between S-ASM release and the concomitant decrease in L-ASM activity significantly. The increase in the S- to L-ASM activity ratio of the 4LA-variant was significantly lower than for the ASM wild-type with 6LA-repeat upon stimulation with TNF $\alpha$.

This genetic effect could have important implications for the immunologic reactions of individuals carrying 4 repeats. Possibly, the difference in S-ASM activity between individuals homozygous for 4 repeats and those for 6 repeats in our in vivo study might result from the current individual and prevalent immunologic reaction. From an evolutionary point of view, the high number of repeats in humans with the higher adaptive potential in ASM activity regulation could be advantageous and more recent since the ASM encoding gene of other primate species with known sequence (Ensembl database) contains consistently less repeats. Alignment to the ASM wild-type sequence with 6LA-repeat in humans reveals a 5LA-repeat for Orangutan (Pongo abelii) and Macaque (Macaca mulatta), a 4LA-repeat for Chimpanzee (Pan troglodytes) and only a 3LA-repeat for Gorilla (Gorilla gorilla gorilla), Gibbon (Nomascus leucogenys), Bushbaby (Otolemur garnettii), Marmoset (Callithrix jacchus) and Mouse Lemur (Microcebus murinus).

Overall, the length of the ASM signal peptide TMD could be essential for the exact sorting and trafficking of ASM into highly specialised vesicles. It was shown that ASM co-localises with dysferlin to specific cellular vesicles during plasma membrane repair [68] and with syntaxin 4 upon stress responses to translocate to the plasma membrane via the exocytic pathway [69]. Interestingly, the syntaxin isoforms display distinct TMD lengths of their signal peptide that determine their localisation either to the Golgi or the plasma membrane [59]. Thus, the ASM TMD length seems to be optimised for its specific tasks in the cell.

However, there were some limitations of our study that should be considered. Although our clinical studies GENES and ASPECT comprised 289 healthy individuals in total, only a few individuals were homozygous for the rare allele with 4 repeats, which were needed for more powerful analyses. In our in vitro study, biochemical analyses of ASM resulted in very similar processing patterns for variants with 3 to 7 repeats, in contrast to the differential effects already seen for 4 repeats in vivo.

Taken together, our data provide first evidence that the length of the ASM signal peptide is essential for tapping the full secretion potential of the protein. The consequences of impaired ASM secretion for clinical populations have yet to be defined.

\section{Acknowledgements}

We thank Stefan Hofmann, Franziska Kreß and Sabine Müller for excellent technical assistance. The authors are also grateful to Cornelia Kraus from the Department of Human Genetics in Erlangen for her kind support with the Genetic Analyzer. This work was supported by the Scholarship Programme 'Equality for Women in Research and Teaching', University Erlangen-Nuremberg (to CR). 
Rhein et al.: Function of the ASM Signal Peptide

\section{References}

1 Quintern LE, Weitz G, Nehrkorn H, Tager JM, Schram AW, Sandhoff K: Acid sphingomyelinase from human urine: Purification and characterization. Biochim Biophys Acta 1987;922:323-336.

- Herr I, Wilhelm D, Böhler T, Angel P, Debatin KM: Activation of CD95 (APO-1/Fas) signaling by ceramide mediates cancer therapy-induced apoptosis. Embo J 1997;16:6200-6208.

-3 Quintans J, Kilkus J, McShan CL, Gottschalk AR, Dawson G: Ceramide mediates the apoptotic response of wehi 231 cells to anti-immunoglobulin, corticosteroids and irradiation. Biochem Biophys Res Commun 1994;202:710-714.

4 Kolesnick RN, Goni FM, Alonso A: Compartmentalization of ceramide signaling: Physical foundations and biological effects. J Cell Physiol 2000;184:285-300.

-5 Holopainen JM, Subramanian M, Kinnunen PK: Sphingomyelinase induces lipid microdomain formation in a fluid phosphatidylcholine/sphingomyelin membrane. Biochemistry 1998;37:17562-17570.

6 Nurminen TA, Holopainen JM, Zhao H, Kinnunen PK: Observation of topical catalysis by sphingomyelinase coupled to microspheres. J Am Chem Soc 2002;124:12129-12134.

7 Grassmé H, Jekle A, Riehle A, Schwarz H, Berger J, Sandhoff K, Kolesnick R, Gulbins E: CD95 signaling via ceramide-rich membrane rafts. J Biol Chem 2001;276:20589-20596.

8 Grassmé H, Riethmüller J, Gulbins E: Biological aspects of ceramide-enriched membrane domains. Prog Lipid Res 2007;46:161-170.

-9 Carpinteiro A, Dumitru C, Schenck M, Gulbins E: Ceramide-induced cell death in malignant cells. Cancer Lett 2008;264:1-10.

10 Pettus BJ, Chalfant CE, Hannun YA: Sphingolipids in inflammation: Roles and implications. Curr Mol Med 2004;4:405-418.

11 Ogretmen B, Hannun YA: Biologically active sphingolipids in cancer pathogenesis and treatment. Nat Rev Cancer 2004;4:604-616.

$>12$ Spiegel S, Cuvillier O, Edsall LC, Kohama T, Menzeleev R, Olah Z, Olivera A, Pirianov G, Thomas DM, Tu Z, Van Brocklyn JR, Wang F: Sphingosine-1-phosphate in cell growth and cell death. Ann N Y Acad Sci 1998;845:11-18.

13 Spiegel S, Merrill AH Jr: Sphingolipid metabolism and cell growth regulation. FASEB J 1996;10:1388-1397.

14 Schissel SL, Schuchman EH, Williams KJ, Tabas I: Zn ${ }^{2+}$-stimulated sphingomyelinase is secreted by many cell types and is a product of the acid sphingomyelinase gene. J Biol Chem 1996;271:18431-18436.

15 Jenkins RW, Canals D, Idkowiak-Baldys J, Simbari F, Roddy P, Perry DM, Kitatani K, Luberto C, Hannun YA: Regulated secretion of acid sphingomyelinase: Implications for selectivity of ceramide formation. J Biol Chem 2010;285:35706-35718.

16 Schissel SL, Keesler GA, Schuchman EH, Williams KJ, Tabas I: The cellular trafficking and zinc dependence of secretory and lysosomal sphingomyelinase, two products of the acid sphingomyelinase gene. J Biol Chem 1998;273:18250-18259.

17 Ferlinz K, Hurwitz R, Vielhaber G, Suzuki K, Sandhoff K: Occurrence of two molecular forms of human acid sphingomyelinase. Biochem J 1994;301:855-862.

18 Hurwitz R, Ferlinz K, Vielhaber G, Moczall H, Sandhoff K: Processing of human acid sphingomyelinase in normal and I-cell fibroblasts. J Biol Chem 1994;269:5440-5445.

19 Bartelsen O, Lansmann S, Nettersheim M, Lemm T, Ferlinz K, Sandhoff K: Expression of recombinant human acid sphingomyelinase in insect sf21 cells: Purification, processing and enzymatic characterization. J Biotechnol 1998;63:29-40.

20 Ferlinz K, Hurwitz R, Moczall H, Lansmann S, Schuchman EH, Sandhoff K: Functional characterization of the n-glycosylation sites of human acid sphingomyelinase by site-directed mutagenesis. Eur J Biochem 1997;243:511-517.

-21 Qiu H, Edmunds T, Baker-Malcolm J, Karey KP, Estes S, Schwarz C, Hughes H, Van Patten SM: Activation of human acid sphingomyelinase through modification or deletion of C-terminal cysteine. J Biol Chem 2003;278:32744-32752.

22 Lansmann S, Ferlinz K, Hurwitz R, Bartelsen O, Glombitza G, Sandhoff K: Purification of acid sphingomyelinase from human placenta: Characterization and N-terminal sequence. FEBS Lett 1996;399:227-231. 
Rhein et al.: Function of the ASM Signal Peptide

23 Wong ML, Xie B, Beatini N, Phu P, Marathe S, Johns A, Gold PW, Hirsch E, Williams KJ, Licinio J, Tabas I: Acute systemic inflammation up-regulates secretory sphingomyelinase in vivo: A possible link between inflammatory cytokines and atherogenesis. Proc Natl Acad Sci U S A 2000;97:8681-8686.

24 Romiti E, Vasta V, Meacci E, Farnararo M, Linke T, Ferlinz K, Sandhoff K, Bruni P: Characterization of sphingomyelinase activity released by thrombin-stimulated platelets. Mol Cell Biochem 2000;205:75-81.

25 Marathe S, Schissel SL, Yellin MJ, Beatini N, Mintzer R, Williams KJ, Tabas I: Human vascular endothelial cells are a rich and regulatable source of secretory sphingomyelinase. Implications for early atherogenesis and ceramide-mediated cell signaling. J Biol Chem 1998;273:4081-4088.

-26 Brady RO, Kanfer JN, Mock MB, Fredrickson DS: The metabolism of sphingomyelin. II. Evidence of an enzymatic deficiency in Niemann-Pick disease. Proc Natl Acad Sci U S A 1966;55:366-369.

27 Selzner M, Bielawska A, Morse MA, Rüdiger HA, Sindram D, Hannun YA, Clavien PA: Induction of apoptotic cell death and prevention of tumor growth by ceramide analogues in metastatic human colon cancer. Cancer Res 2001;61:1233-1240.

28 Riboni L, Campanella R, Bassi R, Villani R, Gaini SM, Martinelli-Boneschi F, Viani P, Tettamanti G: Ceramide levels are inversely associated with malignant progression of human glial tumors. Glia 2002;39:105-113.

29 He X, Huang Y, Li B, Gong CX, Schuchman EH: Deregulation of sphingolipid metabolism in Alzheimer's disease. Neurobiol Aging 20010;31:398-408.

-30 Kornhuber J, Medlin A, Bleich S, Jendrossek V, Henkel AW, Wiltfang J, Gulbins E: High activity of acid sphingomyelinase in major depression. J Neural Transm 2005;112:1583-1590.

-31 Reichel M, Greiner E, Richter-Schmidinger T, Yedibela O, Tripal P, Jacobi A, Bleich S, Gulbins E, Kornhuber J: Increased acid sphingomyelinase activity in peripheral blood cells of acutely intoxicated patients with alcohol dependence. Alcohol Clin Exp Res 2010;34:46-50.

-32 Grassmé H, Jendrossek V, Riehle A, von Kürthy G, Berger J, Schwarz H, Weller M, Kolesnick R, Gulbins E: Host defense against pseudomonas aeruginosa requires ceramide-rich membrane rafts. Nat Med 2003;9:322-330.

-33 Mikati MA, Zeinieh M, Habib RA, El Hokayem J, Rahmeh A, El Sabban M, Usta J, Dbaibo G: Changes in sphingomyelinases, ceramide, $\mathrm{Bax}_{2} \mathrm{Bcl}_{2}$, and caspase-3 during and after experimental status epilepticus. Epilepsy Res 2008;81:161-166.

34 Teichgräber V, Ulrich M, Endlich N, Riethmüller J, Wilker B, De Oliveira-Munding CC, van Heeckeren AM, Barr ML, von Kürthy G, Schmid KW, Weller M, Tümmler B, Lang F, Grassmé H, Doring G, Gulbins E: Ceramide accumulation mediates inflammation, cell death and infection susceptibility in cystic fibrosis. Nat Med 2008;14:382-391.

35 Reichel M, Beck J, Mühle C, Rotter A, Bleich S, Gulbins E, Kornhuber J: Activity of secretory sphingomyelinase is increased in plasma of alcohol-dependent patients. Alcohol Clin Exp Res 2011;35:1852-1859.

-36 Lang PA, Schenck M, Nicolay JP, Becker JU, Kempe DS, Lupescu A, Koka S, Eisele K, Klarl BA, Rubben H, Schmid KW, Mann K, Hildenbrand S, Hefter H, Huber SM, Wieder T, Erhardt A, Haussinger D, Gulbins E, Lang F: Liver cell death and anemia in wilson disease involve acid sphingomyelinase and ceramide. Nat Med 2007;13:164-170.

-37 Doehner W, Bunck AC, Rauchhaus M, von Haehling S, Brunkhorst FM, Cicoira M, Tschope C, Ponikowski P, Claus RA, Anker SD: Secretory sphingomyelinase is upregulated in chronic heart failure: A second messenger system of immune activation relates to body composition, muscular functional capacity, and peripheral blood flow. Eur Heart J 2007;28:821-828.

-38 Claus RA, Bunck AC, Bockmeyer CL, Brunkhorst FM, Losche W, Kinscherf R, Deigner HP: Role of increased sphingomyelinase activity in apoptosis and organ failure of patients with severe sepsis. FASEB J 2005;19:1719-1721.

-39 Grammatikos G, Mühle C, Ferreiros N, Schroeter S, Bogdanou D, Schwalm S, Hintereder G, Kornhuber J, Zeuzem S, Sarrazin C, Pfeilschifter J: Serum acid sphingomyelinase is upregulated in chronic hepatitis C infection and non alcoholic fatty liver disease. Biochim Biophys Acta 2014;1841:1012-1020.

40 Marathe S, Kuriakose G, Williams KJ, Tabas I: Sphingomyelinase, an enzyme implicated in atherogenesis, is present in atherosclerotic lesions and binds to specific components of the subendothelial extracellular matrix. Arterioscler Thromb Vasc Biol 1999;19:2648-2658. 
Rhein et al.: Function of the ASM Signal Peptide

41 Göggel R, Winoto-Morbach S, Vielhaber G, Imai Y, Lindner K, Brade L, Brade H, Ehlers S, Slutsky AS, Schütze S, Gulbins E, Uhlig S: PAF-mediated pulmonary edema: A new role for acid sphingomyelinase and ceramide. Nat Med 2004;10:155-160.

42 Petrache I, Natarajan V, Zhen L, Medler TR, Richter AT, Cho C, Hubbard WC, Berdyshev EV, Tuder RM: Ceramide upregulation causes pulmonary cell apoptosis and emphysema-like disease in mice. Nat Med 2005;11:491-498.

43 Rhein C, Naumann J, Mühle C, Zill P, Adli M, Hegerl U, Hiemke C, Mergl R, Möller H-J, Reichel M, Kornhuber J: The acid sphingomyelinase sequence variant p.A487V is not associated with decreased levels of enzymatic activity. JIMD Rep 2013;8:1-6.

44 Dastani Z, Ruel IL, Engert JC, Genest J Jr, Marcil M: Sphingomyelin phosphodiesterase-1 (SMPD1) coding variants do not contribute to low levels of high-density lipoprotein cholesterol. BMC Med Genet 2007;8:79.

45 Reichel M, Richter-Schmidinger T, Mühle C, Rhein C, Alexopoulos P, Schwab SG, Gulbins E, Kornhuber J: The common acid sphingomyelinase polymorphism G508R is associated with self-reported allergy. Cell Physiol Biochem 2014;34:82-91.

-46 Schuchman EH, Levran 0, Suchi M, Desnick RJ: An MspI polymorphism in the human acid sphingomyelinase gene (SMPD1). Nucleic Acids Res 1991;19:3160.

47 Wan Q, Schuchman EH: A novel polymorphism in the human acid sphingomyelinase gene due to size variation of the signal peptide region. Biochim Biophys Acta 1995;1270:207-210.

48 Alexopoulos P, Richter-Schmidinger T, Horn M, Maus S, Reichel M, Sidiropoulos C, Rhein C, Lewczuk P, Doerfler A, Kornhuber J: Hippocampal volume differences between healthy young apolipoprotein E $\varepsilon 2$ and ¿4 carriers. J Alzheimers Dis 2011;26:207-210.

49 Richter-Schmidinger T, Alexopoulos P, Horn M, Maus S, Reichel M, Rhein C, Lewczuk P, Sidiropoulos C, Kneib T, Perneczky R, Doerfler A, Kornhuber J: Influence of brain-derived neurotrophic-factor and apolipoprotein E genetic variants on hippocampal volume and memory performance in healthy young adults. J Neural Transm 2011;118:249-257.

50 Rhein C, Mühle C, Richter-Schmidinger T, Alexopoulos P, Doerfler A, Kornhuber J: Neuroanatomical correlates of intelligence in healthy young adults: The role of basal ganglia volume. PLOS ONE 2014;9:e93623.

51 Rhein C, Tripal P, Seebahn A, Konrad A, Kramer M, Nagel C, Kemper J, Bode J, Mühle C, Gulbins E, Reichel M, Becker CM, Kornhuber J: Functional implications of novel human acid sphingomyelinase splice variants. PLOS ONE 2012;7:e35467.

52 Stephens M, Donnelly P: A comparison of Bayesian methods for haplotype reconstruction from population genotype data. Am J Hum Genet 2003;73:1162-1169.

53 Kochl R, Alken M, Rutz C, Krause G, Oksche A, Rosenthal W, Schulein R: The signal peptide of the G proteincoupled human endothelin B receptor is necessary for translocation of the N-terminal tail across the endoplasmic reticulum membrane. J Biol Chem 2002;277:16131-16138.

54 von Heijne G: Signal sequences. The limits of variation. J Mol Biol 1985;184:99-105.

55 von Heijne G: Towards a comparative anatomy of N-terminal topogenic protein sequences. J Mol Biol 1986;189:239-242.

56 Martoglio B, Dobberstein B: Signal sequences: More than just greasy peptides. Trends Cell Biol 1998;8:410415.

57 Hegde RS, Bernstein HD: The surprising complexity of signal sequences. Trends Biochem Sci 2006;31:563571.

58 Bulbarelli A, Sprocati T, Barberi M, Pedrazzini E, Borgese N: Trafficking of tail-anchored proteins: Transport from the endoplasmic reticulum to the plasma membrane and sorting between surface domains in polarised epithelial cells. J Cell Sci 2002;115:1689-1702.

59 Watson RT, Pessin JE: Transmembrane domain length determines intracellular membrane compartment localization of syntaxins 3, 4, and 5. Am J Physiol Cell Physiol 2001;281:C215-223.

60 Visvikis S, Chan L, Siest G, Drouin P, Boerwinkle E: An insertion deletion polymorphism in the signal peptide of the human apolipoprotein B gene. Hum Genet 1990;84:373-375.

-61 Sturley SL, Talmud PJ, Brasseur R, Culbertson MR, Humphries SE, Attie AD: Human apolipoprotein B signal sequence variants confer a secretion-defective phenotype when expressed in yeast. J Biol Chem 1994;269:21670-21675. 


\begin{tabular}{|c|c|c|}
\hline Cellula & Cell Physiol Biochem 2014;34:1385-1401 & \\
\hline and Biochemistry & $\begin{array}{l}\text { DOI: 10.1159/000366345 } \\
\text { Publisnea online: October 02, } 2014\end{array}$ & $\begin{array}{l}\text { O } 2014 \text { S. Karger AG, Basel } \\
\text { www.karger.com/cpb }\end{array}$ \\
\hline
\end{tabular}

62 Xu CF, Tikkanen MJ, Huttunen JK, Pietinen P, Butler R, Humphries S, Talmud P: Apolipoprotein B signal peptide insertion/deletion polymorphism is associated with Ag epitopes and involved in the determination of serum triglyceride levels. J Lipid Res 1990;31:1255-1261.

63 Saha N, Tay JS, Chew LS: Influence of apolipoprotein B signal peptide insertion/deletion polymorphism on serum lipids and apolipoproteins in a chinese population. Clin Genet 1992;41:152-156.

64 Ng TW, Ooi EM, Watts GF, Chan DC, Barrett PH: Genetic determinants of apolipoprotein B-100 kinetics. Curr Opin Lipidol 2010;21:141-147.

65 Halsall DJ, Martensz ND, Luan J, Maison P, Wareham NJ, Hales CN, Byrne CD: A common apolipoprotein B signal peptide polymorphism modifies the relation between plasma non-esterified fatty acids and triglyceride concentration in men. Atherosclerosis 2000;152:9-17.

66 Boekholdt SM, Peters RJ, Fountoulaki K, Kastelein JJ, Sijbrands EJ: Molecular variation at the apolipoprotein $\mathrm{B}$ gene locus in relation to lipids and cardiovascular disease: A systematic meta-analysis. Hum Genet 2003;113:417-425.

67 Hegde RS: Targeting and beyond: New roles for old signal sequences. Mol Cell 2002;10:697-698.

68 Defour A, Van der Meulen JH, Bhat R, Bigot A, Bashir R, Nagaraju K, Jaiswal JK: Dysferlin regulates cell membrane repair by facilitating injury-triggered acid sphingomyelinase secretion. Cell Death Dis 2014;5:e1306.

69 Perrotta C, Bizzozero L, Cazzato D, Morlacchi S, Assi E, Simbari F, Zhang Y, Gulbins E, Bassi MT, Rosa P, Clementi E: Syntaxin 4 is required for acid sphingomyelinase activity and apoptotic function. J Biol Chem 2010;285:40240-40251. 